\title{
IMAGENS DE SI NO DISCURSO: CENOGRAFIAS E ETHÉ DISCURSIVOS DA EMPREENDEDORA BEL PESCE NA WEB
}

\author{
Self image in the speech: cenographies and ethe discursives \\ of the entrepreneur Bel Pesce on the web
}

\begin{abstract}
Imágenes de sí en el discurso: escenografía y los ethé discursivos de la empreendedora Bel Pesce en la web
\end{abstract}

\author{
Eliane Davila dos Santos \\ Doutoranda em Processos e Manifestações Culturais. \\ Universidade Feevale \\ eliane.d@feevale.br \\ Ernani Cesar de Freitas \\ Professor titular do Programa em Processos e Manifestações Culturais \\ ernanic@feevale.br
}

\section{Resumo}

Os diálogos propostos no estudo delimitam-se a descrever as cenografias da reportagem sobre Bel Pesce, feita pelo site da pela revista Veja, a fim de identificar os ethé discursivos da empreendedora, construídos pela edição do site da revista e elaborado pela própria empreendedora em uma postagem comunicacional no seu Facebook oficial. Como marco teórico do estudo, utilizam-se os postulados de Maingueneau (2011, 2015, 2016b) e Amossy (2016). A pesquisa é exploratória com abordagem qualitativa, mediante um estudo de caso. As interpretações feitas, nesta pesquisa, encaminham um diálogo, mediante a análise do discurso, para a melhor compreensão do ethos discursivo apoiado em cenografias que emergem da enunciação.

Palavras-chave: Discurso. Ethos discursivo. Empreendedorismo.

\begin{abstract}
The dialogues proposed in the study are limited to describing scenographies of the article written by Veja's magazine site regarding Bel Pesce, so as to identify the entrepreneur discursive ethé built up by the site's magazine edition, and by Pesce communicational post on her official Facebook page. As theoretical framework of the study, one uses Maingueneau's (2011, 2015, 2016b) and Amossy's (2016) postulates. The research methodology is exploratory, with a qualitative approach, through a case study. The interpretations made on this research direct a dialogue, through the speech analysis, to a better understanding of the discursive ethos, supported by scenographies that arise from the enunciation.
\end{abstract}

Key words: Speech. Communication. Discursive ethos. Entrepreneurship. 


\section{Resumen}

Los diálogos propuestos en el estudio se delimitan a describir la escenografía del reportaje sobre Bel Pesce, hecho por el sitio web de la revista Veja, para identificar los ethé discursivos de la emprendedora, construidos por la edición de la página web de la revista y elaborados por la propia emprendedora en una publicación comunicacional en su Facebook oficial. En la base teórica del estudio, se utilizan los postulados de Maingueneau (2011, 2015, 2016b) y Amossy (2016). La investigación es exploratoria de carácter cualitativo, por tratarse de un estudio de caso. Las interpretaciones hechas en esta investigación se remeten a un diálogo, a través del análisis del discurso, para una mejor comprensión del ethos discursivo, apoyado en las escenografías que emergen de la enunciación.

Palabras clave: Discurso. Ethos discurso. Empreendedurismo.

\section{INTRODUÇÃO}

Nos últimos meses, a polêmica envolvendo a empreendedora, escritora e conferencista Bel Pesce foi notícia em diversos espaços midiáticos na internet. Após o fracasso de uma ideia de crowdfunding $^{1}$ para a constituição de uma hamburgueria, os desdobramentos levaram a críticas quanto à veracidade do currículo e do trabalho da empreendedora. Este estudo é delimitado à análise discursiva da reportagem do site da revista Veja, intitulada Caso Bel Pesce reaviva críticas aos 'empreendedores de palco' e uma postagem comunicacional da empreendedora no seu Facebook oficial. Primeiramente, a reportagem do site da revista Veja apresenta o discurso do jornalista Felipe Machado² sobre o caso Bel Pesce; o segundo discurso apresenta uma postagem comunicacional da empreendedora no seu Facebook oficial, figurando como a primeira resposta às criticas midiáticas. Os sites de revistas jornalísticas e as mídias sociais são espaços de produção de sentido e são relevantes por oferecerem materialidades discursivas que permitem trabalhar a noção do ethos articulada à cena de enunciação.

$\mathrm{Na}$ atualidade, os leitores de reportagens jornalísticas na internet e das mídias sociais entram em contato com cenografias construídas pelos enunciadores, mediante elementos discursivos destacados nos textos que podem ser empregados para exaltar ou desabonar a imagem do sujeito em cena diante dos leitores. Analisar as marcas discursivas presentes nas reportagens aprofunda o conhecimento de como se constrói o ethos - como imagens de si - e desvela o papel identitário dos enunciadores.

Este ensaio se insere na linha de pesquisa Linguagem e Processos Comunicacionais. A questão norteadora estabelece que as cenografias construídas na reportagem do site da revista

\footnotetext{
${ }^{1}$ Financiamento coletivo.

${ }^{2}$ Jornalista da revista do site da revista Veja.
} 
Veja, provindas da construção da editorial do site e da postagem no Facebook, emergem as imagens de si - ethé discursivos de Bel Pesce. O objetivo visa descrever as cenografias da reportagem sobre a Bel Pesce, realizada pelo site da revista Veja, a fim de identificar os ethé discursivos $^{3}$ da empreendedora, construídos pela edição do site da revista e elaborado pela própria empreendedora em uma postagem comunicacional no seu Facebook oficial.

O motivo da escolha dos corpora deve-se à polêmica gerada pelos pronunciamentos de Bel Pesce na mídia. As materialidades discursivas põem em jogo dois posicionamentos sobre a Bel Pesce: um que nos dá subsídios para construção do ethos discursivo elaborado pelo site da revista Veja e a concepção do ethos discursivo produzido pela própria empreendedora no Facebook. Os corpora estão disponibilizados na internet, o que facilita o acesso às materialidades, além de se ser um assunto que suscita reflexões quanto à criação da imagem de si em reportagens jornalísticas e redes sociais.

Como marco teórico do estudo, utilizam-se os postulados de Maingueneau (2011, 2015, 2016b) e Amossy (2016), que abarcam questões sobre as cenas de enunciação, o ethos discursivo - como imagem de si. As análises feitas, nesta pesquisa, encaminham o diálogo mediante a análise do discurso para a melhor compreensão do ethos discursivo apoiado em cenografias que emergem da enunciação. A metodologia do estudo segue as recomendações de Prodanov e Freitas (2013), sendo utilizada a pesquisa exploratória com abordagem qualitativa, mediante um estudo de caso. Assim, para melhor organização da pesquisa, as seções estão assim dispostas: primeiramente, trata-se das questões sobre a cena enunciativa. Na próxima seção, mencionam-se questões sobre o ethos e seus desdobramentos. Segue-se com a apresentação da metodologia e, em seguida, com a seção de resultados; ao final, faz-se uma seção de considerações finais.

\section{A CENA ENUNCIATIVA E A CONSTRUÇÃO DO EHOS: A ARTICULAÇÃO DOS CONCEITOS}

As pesquisas sobre a construção de uma imagem de si no discurso são estudadas desde a obra de Maingueneau (2008b), intitulada Gênese dos Discursos, ${ }^{4}$ e demonstram que é

\footnotetext{
${ }^{3}$ Em razão da limitação de páginas do ensaio, utilizam-se, nas análises, apenas as materialidades discursivas verbais dos corpora.

${ }^{4}$ O livro Gênese dos Discursos foi lançado na França em 1984 e traduzido em português décadas depois. Embora não se considere nas análises deste estudo, de forma detalhada, os planos da semântica global, em virtude da limitação de páginas do ensaio, destaca-se que os planos mencionados pelo autor são:
} 
necessário conceber o discurso de forma global e atentar para os planos que o constituem. No entanto, na obra Novas Tendências em Análise do Discurso (1997), o autor articula, além dos itens da semântica global, os conceitos de cenografia e ethos para tratar das cenas de enunciação. A amplitude de se trabalhar com as noções de ethos ${ }^{5}$ coloca em relevo o destaque do enunciador em se conceber, reconhecer seu destinatário e legitimar o seu dizer. O enunciador apresenta certo modo de dizer, uma forma de enunciação (MAINGUENEAU, 2008b).

A problemática do ethos transcende, dessa forma, o quadro argumentativo e a visão retórica apresentada por Aristóteles ${ }^{6}$. Na perspectiva da análise do discurso, o ethos é parte característica da cena de enunciação. Dessa forma, o discurso prevê uma "cena de enunciação para poder ser anunciado, e, por seu turno, ele deve validá-la por sua própria enunciação: qualquer discurso, por seu próprio desdobramento, pretende instituir a situação de enunciação que o torna pertinente.” (MAINGUENEAU, 2016a, p. 75). Propõe uma análise da instância da enunciação, distinguindo três cenas: a cena englobante, a cena genérica e a cenografia. A cena englobante é relacionada ao tipo de discurso: religioso, político, publicitário. A cena genérica é definida pelos gêneros de discurso. Cada gênero ${ }^{7}$ de discurso implica uma cena específica que impõe aos sujeitos interlocutores um modo de inscrição no espaço e no tempo, um suporte material, um modo de circulação, uma finalidade. Não é por meio desse quadro cênico que Maingueneau (2013) relata o confronto dos sujeitos interlocutores, mas pela cenografia, que não é imposta pelo tipo de gênero de discurso, mas instituída pelo próprio discurso. Quanto à cenografia ${ }^{8}$, ela não é prescrita “pelo gênero, ela é construída pelo próprio

intertextualidade, vocabulário, temas, estatuto do enunciador e do destinatário, dêixis enunciativa, modo de enunciação, modo de coesão (MAINGUENEAU, 2008b).

5 “'[...] - o ethos é uma noção discursiva que se constrói através do discurso, não é uma 'imagem' do locutor exterior a sua fala; - o ethos é fundamentalmente um processo interativo de influência sobre o outro; - é uma noção fundamentalmente híbrida (sociodiscursiva), um comportamento socialmente avaliado, que não pode ser apreendido fora de uma situação de comunicação precisa, integrada ela mesma numa determinada conjuntura sócio-histórica." (MAINGUENEAU, 2011, p. 17).

${ }^{6}$ A retórica antiga resume-se em um triângulo caracterizado pelo "logos", "pathos" e ethos. O logos refere-se à lógica do puro argumento e aos tipos de argumentos empregados. O pathos refere-se aos tipos de apelo e reconhecimento dado à audiência, levando em consideração a psicologia social das emoções (MAINGUENEAU, 2015).

${ }^{7}$ Esclarece que, quando se fala em discursos na web, a multimodalidade do meio, muitas vezes, não pode ser analisada pelo modelo tradicional (cena englobante, genérica e cenografia). Quando se fala em redes sociais, blogs, o contexto da cenografia prepondera e as outras cenas ficam "enfraquecidas" (MAINGUENEAU, 2015).

8 "A cenografia, como o ethos de que dela participa, implica um processo de enlaçamento paradoxal: desde sua emergência, a fala supõe uma certa cena de enunciação que, de fato se valida progressivamente por essa mesma enunciação. A cenografia é, assim, ao mesmo tempo, aquela de onde o discurso vem e aquela que ele engendra." (MAINGUENEAU, 2016a, p. 77). 
texto: um sermão pode ser enunciado por meio de uma cenografia professoral, profética etc." (MAINGUENEAU, 2016, p. 75).

O ethos possibilita pensar com mais abrangência sobre a aderência dos sujeitos a um posicionamento discursivo ${ }^{9}$. Pode-se afirmar que o discurso não é definido apenas por uma dêixis e pelo estatuto do enunciador e do destinatário, mas pela forma de dizer, ou seja, um modo de enunciar. Do discurso depreende-se uma voz própria, conforme sugere Bakhtin $(2000)^{10}$, a relevância do tom em textos verbais de qualquer gênero. Assim, pode-se dizer que o discurso comporta um tom, oral ou escrito, o qual "se apoia sobre uma dupla figura do enunciador, a de um caráter e de uma corporalidade, estreitamente associadas." (MAINGUENEAU, 2008b, p. 92, grifo do autor). O tom é compreendido como um valor social, ou seja, um relevo ou um sentido dado à palavra no contexto em que a enunciação é articulada e compreendida por quem recebe a informação. $\mathrm{O}$ tom oportuniza ao receptor do discurso construir "uma representação do corpo enunciador, fazendo emergir uma instância subjetiva que desempenha o papel de fiador ${ }^{11}$ do que é dito." (MAINGUENEAU, 2013, p. 98). A partir dessa ideia, "este é o tipo de fenômeno que, por desdobramento da retórica tradicional, pode se chamar de ethos: por meio da enunciação, revela-se a personalidade do enunciador." (MAINGUENEAU, 2013, p. 97-98). A maneira de dizer, que é também um modo de ser, possibilita a adesão do leitor que é expressa pelo conceito de incorporação ${ }^{12}$ pressupondo um mundo ético ${ }^{13}$ do qual o fiador participa.

O pensamento de que o público produz a representação do ethos e enunciador mesmo antes de ele falar constitui uma diferenciação entre o ethos pré-discursivo e o ethosdiscursivo. Pode-se dizer que a imagem prévia que se faz do orador está baseada em representações culturalmente partilhadas, isto é, nos estereótipos que se cristalizam na cultura

\footnotetext{
9 "O termo posicionamento trata-se de uma categoria de base da análise do discurso, que diz respeito à instauração e à conservação de uma identidade enunciativa.” (CHARAUDEAU; MAINGUENEAU, 2012, p. 392).

${ }^{10}$ Correlaciona-se o conceito de tom de Maingueneau (2008a) ao conceito de entoação de Bakhtin (2000). Por intermédio da entoação, da cena enunciativa, percebe-se a junção entre o discurso verbal e o contexto extraverbal. Qualquer enunciado carrega uma entoação valorativa, um tom volitivo-emocional. Aquilo que não é dito na cena enunciativa ganha relevância apoiado ao conceito de entoação de Bakhtin (2000).

${ }^{11} \mathrm{O}$ fiador é aquele que se revela no discurso. "O destinatário tem construído a figura de um fiador dotado de propriedades físicas (corporalidade) e psicológicas (caráter) apoiando-se em um conjunto difuso de representações sociais avaliadas positiva ou negativamente, de estereótipos que a enunciação contribui para reforçar ou transformar." (MAINGUENEAU, 2016b, p. 14).

12 "O conceito de incorporação exerce três finalidades: a enunciação confere uma corporalidade ao fiador, ela lhe dá corpo; o destinatário incorpora, assimila através da enunciação um conjunto de esquema que correspondem a uma maneira específica de se relacionar com o mundo; essas duas primeiras incorporações permitem a constituição de um corpo, da comunidade imaginária dos que aderem ao mesmo discurso." (MAINGUENEAU, 2016b, p. 14).

${ }^{13}$ Refere-se a cenários estereotipados alusivos a elementos verbais e não verbais.
} 
de um povo, de uma instituição, etc. Quando se pensa em ethos discursivo, logo se vincula a resultados da interação de diversos fatores: ethos pré-discursivo (ethos prévio), ethos discursivo (ethos mostrado), mas também "os fragmentos do texto nos quais o enunciador evoca sua própria enunciação (ethos dito)" - diretamente - "é um amigo que lhe fala" ou "indiretamente, por meio de metáforas ou de alusões a outras cenas de fala, por exemplo." (MAINGUENEAU, 2011, p. 18, grifo do autor). A diferença entre o ethos dito e o ethos mostrado se inscreve nos limites de uma linha; é muito difícil definir uma fronteira cristalina. O ethos efetivo resulta da interação entre as diversas esferas. A Figura 1 ilustra o ethos efetivo e possibilita a compreensão da dinâmica e da complexidade estabelecida na construção do ethos.

Figura 1 - Ethos

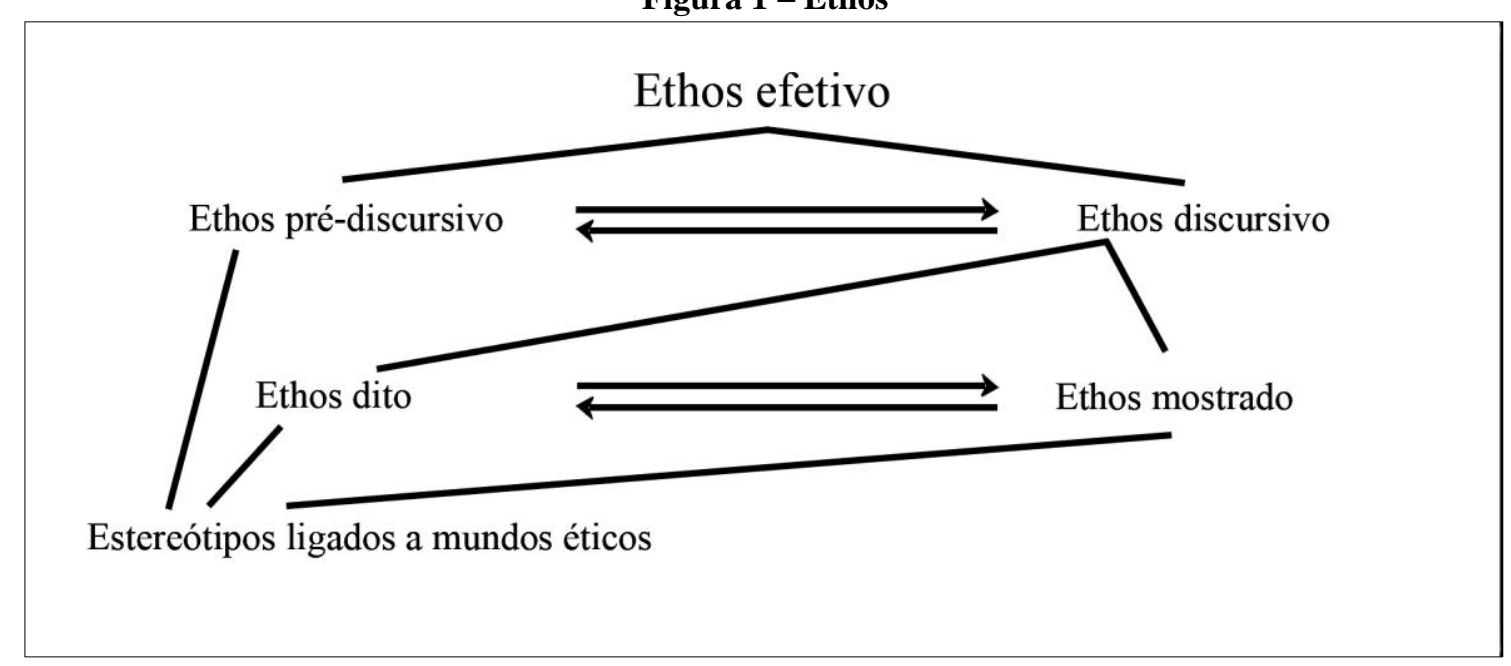

Fonte: Maingueneau (2008a, p. 71)

A construção do ethos discursivo leva à imagem de si. O ethos é instituído por estereótipos construídos socioculturalmente, com o objetivo de formar uma identidade, uma imagem (de si) do enunciador, perante seu público. Na construção da imagem de si, é necessário trazer à discussão e designar um espaço fundamental "ao modo de manifestação material dos discursos, ao seu suporte, bem como ao seu modo de difusão: enunciados orais, no papel, radiofônicos, na tela do computador etc.” (MAINGUENEAU, 2013, p. 81, grifo do autor). Uma mudança na percepção do mídium ${ }^{14}$ modifica o conjunto de um gênero do discurso.

14 "O mídium não é um simples "meio", um simples instrumento para transportar uma mensagem estável: uma mudança importante do mídium modifica o conjunto de um gênero do discurso.” (MAINGUENEAU, 2013, p. 81-82). 
Neste âmbito, buscando entender o espaço midiático em que a construção dos ethé, Charaudeau (2003) concebe que nesse meio ${ }^{15}$ as informações circulam como dispositivos discursivos desprovidos de ingenuidade. A mídia passa a ser um potente produtor de imagens que se distorcem e recebem a atenção de várias esferas sociais. Em realidade, a reflexão parte da ideia de que a mídia desempenha um papel simbólico e afeta os cidadãos, pois regula as trocas sociais e constrói as representações das práticas coletivas. Assim, é em um ambiente, onde a unidade e a pluralidade discursiva se entrecruzam que surgem as imagens de si, ou seja, os ethé discursivos. O item seguinte é dedicado às diretrizes metodológicas para a análise desse estudo.

Neste momento, apresentam-se a fundamentação teórica do trabalho, a metodologia, os resultados e a discussão. O texto poderá ser dividido em seções e subseções, conforme exemplo a seguir.

\section{PERSPECTIVAS METODOLÓGICAS}

A metodologia segue as recomendações de Prodanov e Freitas (2013). Quanto aos procedimentos metodológicos, a pesquisa é de natureza aplicada, com abordagem qualitativa. Assume-se o caráter exploratório; quanto à coleta de dados, os procedimentos são bibliográficos e documentais (corpora), tratando-se de um estudo de caso. O critério da escolha dos objetos empíricos deu-se em razão da polêmica gerada pelos pronunciamentos de Bel Pesce na mídia. Os corpora põem em jogo dois posicionamentos sobre Bel Pesce: um que fornece subsídios para a elaboração do ethos discursivo, produzido pelo site da revista Veja, e a construção do ethos discursivo construído pela própria empreendedora no Facebook. Os corpora estão disponibilizados no site da revista e no Facebook, o que facilita o acesso às materialidades, além de ser um assunto que suscita reflexões quanto à construção da imagem de si em reportagens jornalísticas e redes sociais.

O percurso metodológico deste estudo procura descrever as cenografias da reportagem sobre Bel Pesce, realizada pelo site da revista Veja, a fim de identificar os ethé discursivos da empreendedora construídos pela revista e elaborados pela própria empreendedora, em uma postagem no seu Facebook oficial, configurando como a primeira resposta às críticas midiáticas. Dessa forma, busca-se, neste estudo, fazer uma análise por meio da categoria

\footnotetext{
${ }^{15}$ Destaca-se que os corpora tratam de discursos que se constroem nos espaços midiáticos. O primeiro corpus é elaborado a partir de uma revista digital. O segundo é construído em uma rede social.
} 
teórica: a) Cenografia e ethos: a categoria engloba questões sobre a constituição da cena enunciativa com os conceitos de cena englobante, genérica e cenografia, como concepções que conduzem ao que o discurso cria não somente levando em consideração a figura do enunciador e do coenunciador, mas o todo que emerge da cena de enunciação. É com base na cena enunciativa que se depreendem os ethé discursivos - como imagens de si, que serão identificados considerando-se os estereótipos que circunscrevem o "mundo ético". Os princípios de ethos pré-discursivo, ethos discursivo ${ }^{16}$, além dos conceitos de tom, caráter e fiador do discurso são considerados na análise. O marco teórico do estudo segue os postulados de Maingueneau (2011, 2015, 2016b) e Amossy (2016).

O estudo está organizado da seguinte forma: primeiramente, apresentam-se os corpora: a reportagem do site da revista Veja, intitulada Caso Bel Pesce reaviva críticas aos 'empreendedores de palco' e uma postagem comunicacional do Facebook oficial de Bel Pesce. Logo após, identifica-se a análise dos resultados mediante a categoria teórica cenografia e ethos para cada um dos corpora. Por último, apresentam-se as considerações finais do estudo.

\section{ANÁliSE E RESULTADOS: A CONSTITUIÇÃO DA IMAGEM DE SI}

Inicialmente, apresentam-se os corpora do estudo. O primeiro objeto é uma reportagem do site da revista Veja, intitulada Caso Bel Pesce reaviva críticas aos 'empreendedores de palco ${ }^{17}$, que está disponível no site oficial da revista desde 11 setembro de 2016 ( $8 \mathrm{~h} 54 \mathrm{~min}$ ) - atualizado em 12 setembro de 2016 (9h10min). O segundo objeto é uma postagem comunicacional da empreendedora em seu Facebook ${ }^{18}$ oficial no dia 31 de agosto de 2016. Primeiramente, a reportagem do site da revista Veja apresenta o discurso do jornalista Felipe Machado sobre o caso Pel Besce; o segundo discurso apresenta uma postagem comunicacional da empreendedora no seu Facebook oficial, figurando como a primeira resposta às criticas midiáticas. A polêmica diante do discurso de Bel Pesce iniciou quando a empreendedora aventurou-se para arrecadar fundos em um crowdfunding para iniciar um novo negócio - uma hamburgueria gourmet - juntamente com o vencedor do

\footnotetext{
${ }^{16}$ Ethos dito e ethos mostrado.

${ }^{17}$ Texto na íntegra disponível em: < http://veja.abril.com.br/economia/caso-bel-pesce-reaviva-criticas-aosempreendedores-de-palco/>.

${ }^{18}$ Texto na íntegra disponível em: < https://www.facebook.com/BelPesce/posts/1415148921846413>.
} 
Masterchef Brasi1 ${ }^{19}$ - Leonardo Young - e mais um sócio brasileiro em 2016. Desde então, as críticas denunciavam que Bel Pesce não correspondia a tudo que ela dizia na mídia, colocando-se em dúvida sua credibilidade. Prosseguindo no estudo, passa-se à análise da categoria teórica do primeiro corpus.

\subsection{Reportagem da Revista Veja: Cenografia e Ethos}

$\mathrm{Na}$ análise do primeiro corpus, a reportagem do site da revista Veja, segue-se com a categoria cenografia e ethos, respeitando o trajeto feito em busca da trilha metodológica para a concepção do ethos como imagem de si. Destaca-se a construção das cenas enunciativas: 1) cena englobante: o documento analisado constitui um discurso jornalístico; 2) cena genérica: trata-se de uma reportagem jornalística; 3) a cenografia elaborada pelo site da revista Veja 20 possibilita ao leitor entrar em contato com fatos da vida profissional da empreendedora e fatos polêmicos $^{21}$ que colocaram Bel Pesce em uma situação deconfortável na mídia. $\mathrm{O}$ coenunicador é convidado a adentrar na cenografia como se fosse um investigador que toma ciência dos fatos. Maingueneau (2016a) assevera que o discurso se valida pela própria enunciação e a reportagem vai instituindo a situação de enunciação que ocasionou as críticas aos possíveis "empreendedores de palco", conforme marcas textuais. A cenografia faz um questionamento às atitudes de Bel Pesce e à possível vinculação da empreendedora ao termo pejorativo $^{22}$, além de interpelar o leitor à reflexão sobre os êxitos e sua conduta ética na sua vida profissional. O enunciador da revista, pelo seu modo de dizer (MAINGUENEAU, 2008b), pelo tom ${ }^{23}$ utilizado nas marcas verbais: foi questionada publicamente sobre seu currículo; em seguida, ela corrigiu informações sobre sua formação e experiência profissional, possibilita ao receptor do discurso uma representação ${ }^{24}$ do enunciador que o coloca como fiador do discurso proferido, situando-se como questionador das atitudes da empreendedora, além de reavivar questões que sugerem questionamento de dúvida sobre o brilhantismo profissional de Bel Pesce. As marcas discursivas: os pontos de maior

\footnotetext{
${ }^{19}$ Reality Show brasileiro de comida gourmet.

${ }^{20}$ Pelo jornalista Felipe Machado.

${ }^{21}$ Fracasso do financiamento coletivo; informações em desacordo no seu currículo.

${ }^{22} \mathrm{O}$ empreendedorismo de palco refere-se a palestrantes que são bons, cativam o público, mas que não possuem uma vivência profissional e que não teriam nada a agregar além de frases de efeito e ideias vazias.

${ }^{23}$ Pode ser associado ao conceito de entoação de Bakhtin (2000).

${ }^{24} \mathrm{O}$ caráter e a corporalidade (MAINGUENEAU, 2008).
} 
controvérsia em seu currículo, e que deram argumentos aos detratores, foram o número de diplomas e o papel que teve em algumas das empresas em que trabalhou; antes da polêmica, sua página pessoal dizia que ela possui cinco formações pelo renomado Massachusetts Institute of Technology (MIT); agora, sabe-se que são dois diplomas do tipo majors, que podem ser comparados a uma graduação, e dois minors, uma formação mais curta, no site da revista Veja, sugerem para a empreendedora um ethos que questiona sua credibilidade. É importante destacar que o modo como a revista direciona seu discurso contribui para a construção do ethos da empreendedora. O ambiente midiático potencializa a construção de posicionamentos e os coenunciadores são levados a elaborar o ethos da empreendedora a partir do posicionamento da revista. Pode-se perceber que o mídium digital, utilizado pela revista, apresenta fatos colocam em cheque as informações curriculares de Bel Pesce. A propagação das informações da revista atingem todos os tipos de públicos que tendem a considerar seus argumentos (CHARAUDEAU, 2003) para depreender o ethos da empreendedora.

A construção textual, a maneira de dizer da revista, oportuniza a adesão ${ }^{25}$ do leitor a um mundo ético (MAINGUENEAU, 2016b), que sugere um posicionamento crítico sobre as ações dos empreendedores como Bel Pesce e Luiz Martins ${ }^{26}$. O mundo ético dos empreendedores e dos conferencistas é repleto de glamour, porém a visão estereotipada sugere visões distorcidas das identidades desses sujeitos. $\mathrm{O}$ ethos prévio alude à ideia de que o site da revista Veja vai apresentar os principais fatos sobre o caso Bel Pesce. Os leitores do site da revista e a população em geral estão divididos sobre as polêmicas acerca da empreendedora e palestrante: alguns eleitores podem pressupor que Bel Pesce foi criticada injustamente e a outra parcela supõe que a conferencista exagerou ao promover-se na mídia. É o que se percebe nestas marcas enunciativo-discursivas os paralelos entre Marins ${ }^{27}$ e Pesce não se restringem à controvérsia sobre o currículo; suas palestras são recheadas por raciocínios como "o perigo não é você pensar grande, mas pensar pequeno" e "sem entusiasmo, o sucesso é impossível”.

Um dos nomes citados nas redes sociais pelos críticos do chamado empreendedorismo de palco foi o de Cris Franklin ${ }^{28}$. Associa-se a empreendedora a outros conferencistas que também foram alvo da mesma polêmica de Bel Pesce. O site da revista Veja convoca os

\footnotetext{
${ }^{25}$ Incorporação (MAINGUENEAU, 2016b).

26 Palestrante que teve seu currículo questionado conforme a reportagem.

${ }^{27}$ Luiz Marins é palestrante motivacional.

${ }^{28}$ Cristiane Frankline é empreendedora digital e possui o site http://www.crisfranklin.com.br/
} 
enunciadores a aderir ao discurso construindo um ethos dito de dúvida em relação à competência acadêmica e profissional da palestrante. As pistas discursivas caso Bel Pesce reaviva criticas aos 'empreendedores de palco'; palestrantes que cativam em suas apresentações, voltadas a empresários iniciantes, mesmo que, muitas vezes baseadas apenas em frases de efeito, interpelam o leitor ao mundo ético dos empreendedores que possuem um currículo lacônico - sem experiência para dar testemunho do que falam. $\mathrm{O}$ ethos mostrado pela cena enunciativa questiona a competência e know-how de Bel Pesce. O fiador do discurso faz com que o coenunciador incorpore um conjunto de esquemas da comunidade imaginária que adere ao mesmo discurso, assimilados pela enunciação do site da revista Veja, o que permite evidenciar traços de desconfiança em relação ao ethos de competência de Bel Pesce. Procede-se, agora, à análise da categoria teórica do segundo corpus.

\subsection{Postagem Comunicacional no Facebook: Cenografia e Ethos}

O segundo corpus, ou seja, a postagem comunicacional da empreendedora em seu Facebook Oficial, sob a categoria eleita cenografia $e$ ethos, evidencia-se que a cena englobante (discursos na web) e a cena genérica (postagem em rede social - Facebook) são “enfraquecidas" ${ }^{29}$ quando se fala em sites de relacionamento. A cenografia, no Facebook, isto é, a encenação feita na postagem das redes sociais, ganha importância central para análise do corpus, para se compreender a cena enunciativa (MAINGUENEAU, 2015). Assim, Bel Pesce constrói uma cenografia que busca interpelar os coenunciadores (os seus seguidores na internet), de forma emotiva, para que se identifiquem com ela. A cenografia manifestada apresenta a empreendedora como se fosse vítima das questões confusas que circulam na internet a respeito da sua vida acadêmica e profissional. Bel Pesce sugere, nessa primeira comunicação em seu Facebook oficial, dar uma resposta detalhada às pessoas que acompanham seu trabalho.

A construção textual da postagem comunicacional de Bel Pesce no Facebook possibilita a adesão dos seguidores da rede social a um mundo ético das celebridades empreendedoras que são vítimas de polêmicas pouco fundamentadas no espaço midiático. $\mathrm{O}$ ethos prévio aponta para que Bel Pesce esclareça as confusões geradas a partir das suas entrevistas e comunicações anteriores à polêmica. Sabe-se que existe uma parcela de seus

\footnotetext{
${ }^{29} \mathrm{O}$ termo enfraquecida dá a ideia de multimodalidade da web, principalmente quando se fala em redes sociais, blogs, fóruns, pois dificulta a convenção de uma restrição de gênero clássico como é identificada fora da web
} 
seguidores na rede social que não acreditam em tais calúnias, mas existe outra parcela de pessoas que pôs em dúvida a credibilidade e idoneidade da moça. As marcas enunciativodiscursivas "essa confusão que está rolando ao redor do meu trabalho e principalmente da minha vida pessoal" evidenciam que o ethos de boa moça possa ter sido abalado e o que ela pretende é reestabelecer um ethos de credibilidade e idoneidade. O tom (MAINGUENEAU, 2008b), por meio de traços psicológicos (caráter) e traços físicos (corporalidade) utilizados pela empreendedora, torna-a fiadora de um discurso de restabelecimento da integridade do seu ethos. Sugere-se que os coenunciadores incorporem esse apelo de esclarecer os fatos polêmicos. As marcas discursivas "terei uma resposta para aqueles que me seguem e acreditam no meu trabalho; como já diria o ditado, 'qualquer ser humano visto de perto tem imperfeições', por isso na minha resposta vou expor fatos e também deixar claro todo o meu lado humano" sugerem que o ethos dito é construído para demonstrar que a empreendedora possui credibilidade, idoneidade e que está disposta a esclarecer os fatos. As marcas “desconstruções propositais de imagens são muito comuns no universo dos haters, são feitas por um 'embaralhamento' de informações, com a intenção de levar cada fato a um duplo sentido confundindo as pessoas" manifestam que ela foi vítima de hater ${ }^{30}$, empregando informações equivocadas para denegrir sua imagem. $\mathrm{O}$ ethos mostrado pela cena enunciativa evidencia que Bel Pesce revela sua determinação em esclarecer os fatos. Os coenunciadores são interpelados à adesão do discurso de que ela continua a ter um ethos de empreendedora de sucesso e que tudo irá se resolver em breve conforme marcas discursivas: "tão logo eu chegue de volta ao Brasil (estou no momento em uma viagem no Vale do Silício com alunos), terei uma resposta para aqueles que me seguem e acreditam no meu trabalho." Como já foi mencionado no primeiro corpus, o mídium utilizado pela empreendedora permite a transgressão clássica dos gêneros convencionais $^{31}$ discursivos, pois nas redes sociais, o ambiente possibilita ao fiador do discurso, por meio da cenografia construída, expressar-se de forma a revelar sua própria maneira de comunicar-se.

Portanto, pode-se dizer que a construção do ethos de Bel Pesce no primeiro corpus revela-se como questionador das atitudes acadêmicas e sobre sua vida profissional. O ethos põe em jogo a credibilidade da empreendedora, associando seu nome a outros conferencistas que são chamados de "empreendedores de palco". No segundo corpus, observa-se que a

\footnotetext{
30 O termo hater é amplamente utilizado para identificar aqueles que odeiam, isto é, para Bel Pesce, trata-se de uma situação de "bullying virtual".

${ }^{31}$ Trata-se aqui de compreender que na web a cenografia é preponderante á cena genérica e á cena englobante.
} 
empreendedora constrói um ethos que procura reestabelecer sua credibilidade e idoneidade na web.

\section{CONSIDERAÇÕES FINAIS}

O estudo tematizou a construção dos ethé discursivos - como imagem de si de Bel Pesce em dois espaços comunicacionais na internet. Os sites de revistas jornalísticas e as mídias sociais são espaços de produção de sentido e são relevantes por oferecerem materialidades discursivas que permitem trabalhar a noção do ethos articulada à cena de enunciação.

A questão norteadora estabeleceu que as cenografias construídas na reportagem do site da revista Veja, provindas da construção da editorial do site e da postagem no Facebook, emergem as imagens de si - ethé discursivos de Bel Pesce. O objetivo visou descrever as cenografias da reportagem sobre a Bel Pesce, realizada pelo site da revista Veja, a fim de identificar os ethé discursivos da empreendedora construídos pela edição do site da revista e elaborados pela própria empreendedora em uma postagem comunicacional no seu Facebook oficial.

O estudo foi de grande valia, pois possibilitou reflexões empíricas sobre a construção dos ethé discursivos em espaços na internet para a Linha de Pesquisa Linguagem em Processos Comunicacionais. Apresentaram-se dois estudos de caso: 1) análise discursiva da reportagem do site da revista Veja, intitulada Caso Bel Pesce reaviva críticas aos 'empreendedores de palco'; 2) análise discursiva de uma postagem comunicacional da empreendedora Bel Pesce no seu Facebook oficial. Acredita-se que esses estudos possam contribuir para futuras investigações sobre os aspectos teóricos mobilizados nesta pesquisa. Pode-se considerar como limitação desta pesquisa o fato de a investigação ocorrer apenas em dois estudos de caso. Aconselha-se ampliar, em estudos futuros, a análise de outros objetos empíricos, como vídeos, revistas impressas e programas de TV.

É importante realçar que o ethos é uma noção discursiva que se constrói por meio do discurso. $\mathrm{O}$ ato de tomar a palavra é um convite para que se construa uma imagem de si. $\mathrm{O}$ enunciado se revela pelo tom que o fiador, em uma dinâmica física e psicológica, no qual o coenunciador só é capaz de interpretar por meio do ethos. O ethos o captura e o envolve em um mundo ético e o faz participar da cenografia. Eis a complexidade do estudo do ethos, ou seja, a marca do sujeito no enunciado. 


\section{REFERÊNCIAS}

AMOSSY, Ruth. Da noção retórica de ethos à análise do discurso. In: AMOSSY, Ruth (Org.). Imagens de si no discurso: a construção do ethos. 2. ed. São Paulo: Contexto, 2016a.

BAKHTIN, Mikhail. Estética da criação verbal. Tradução Maria Ermantina Galvão. 3. ed. São Paulo: Martins Fontes, 2000.

CHARAUDEAU, Patrick. El discurso de la información. La construcción del espejo social. Barcelona: Gedisa, Col. El mamífero parlante, 2003.

CHARAUDEAU, Patrick. Discurso das mídias. São Paulo: Contexto, 2009.

CHARAUDEAU, Patrick; MAINGUENEAU, Dominique. Dicionário de análise do discurso. 3. ed. São Paulo: Contexto, 2012.

FACEBOOK. Bel Pesce oficial. Disponível em: <

https://www.facebook.com/BelPesce/posts/1415148921846413 >. Acesso em: 10 nov. 2016.

FRANKLINE, Cristiane. Site de Cris Franklin. Disponível em :<http://www.crisfranklin.com.br $>$. Acesso em: 12 dez. 2016.

MAINGUENEAU, Dominique. Novas tendências em Análise do Discurso. Tradução Freda Indursky. 3. ed. Campinas: Pontes, 1997.

Cenas da enunciação. Organização Sírio Possenti e Maria Cecilia Pérez de Souza-e-Silva. São Paulo: Parábola Editorial, 2008a.

Gênese dos discursos. Tradução Sírio Possenti. São Paulo: Parábola Editorial, 2008b.

A propósito do Ethos. In: MOTTA, Ana Raquel; SALGADO, Luciana (Org.). Ethos discursivo. 2. ed. São Paulo: Contexto, 2011. p. 11-32.

. Análise de textos de comunicação. 6. ed. São Paulo: Cortez, 2013.

. Frases sem texto. São Paulo: Parábola Editorial, 2014.

Discurso e análise do discurso. São Paulo: Parábola Editorial, 2015.

. Ethos, cenografia, incorporação. In: AMOSSY, Ruth (Org.). Imagens de si no discurso. 2. ed. São Paulo: Contexto, 2016a. p. 69-91.

. Retorno crítico sobre o ethos. In: BARONAS, Roberto Leiser; MESTI, Paula Camila; CARREON, Renata de Oliveira (Org.). Análise do discurso: entorno da problemática do ethos, do político e de discursos constituintes. Campinas: Pontes, 2016b. p. 13-33.

PRODANOV, Cleber Cristiano; FREITAS, Ernani Cesar de. Metodologia do Trabalho Científico: métodos e técnicas da pesquisa e do trabalho acadêmico. 2. ed. Novo Hamburgo: Ed. da Feevale, 2013. Disponível em: <http://www.feevale.br/Comum/midias/8807f05a-14d0-4d5b-b1ad1538f3aef538/E-book\%20Metodologia\%20do\%20Trabalho\%20Cientifico.pdf >. Acesso em: 15 jan. 2016. 
REVISTA VEJA. Caso Bel Pesce reaviva crítica aos empreendedores de palco. Disponível em: < http://veja.abril.com.br/economia/caso-bel-pesce-reaviva-criticas-aos-empreendedores-de-palco/>. Acesso em: 10 nov. 2016.

Original recebido em: 10 de janeiro de 2017

Aceito para publicação em: 28 de setembro de 2017

\section{Eliane Davila dos Santos}

Doutoranda e Mestre em Processos e Manifestações Culturais pela Universidade Feevale (2015); Especialista em Gestão de Serviços pela Unisinos (2003); Gestão de Pessoas pela Unisinos (2001) e Administradora de Empresas pela Feevale (1997). Atualmente é Bolsista de doutorado pela Capes em Processos e Manifestações Culturais na Universidade Feevale, dedicando-se às pesquisas da linguagem, comunicação e análise do discurso.

Ernani Cesar de Freitas

Pós-doutorado em Linguística Aplicada e Estudos da Linguagem - PUC-SP/LAEL (2011);

Doutor em Letras, área de concentração Linguística Aplicada (PUCRS/2006); Mestre em Linguística Aplicada pela Universidade do Vale do Rio dos Sinos (UNISINOS/2002). Possui graduação em LETRAS - Português/ Inglês e respectivas Literaturas, pelo Centro Universitário La Salle (1999). Experiência na área de Letras, com ênfase em Língua Portuguesa e Linguística Aplicada, nos temas relacionados à linguagem e trabalho, texto e discurso, leitura e formação do leitor; na área da Comunicação e cultura: comunicação socioorganizacional, cultura e identidade. Cursou MBA Gestão Empresarial na UFRGS e MBA

Executivo na FGV- -RJ. Professor (Titular) de Ensino Superior na Universidade Feevale, Programa de Pós-graduação em Processos e Manifestações Culturais, e professor permanente no PPG em Letras na Universidade de Passo Fundo (RS).

Esta obra está licenciada sob uma Licença Creative Commons. 